\title{
Synthesis and Anionic Polymerization of Silacyclobutanes Bearing Naphthyl or Biphenyl Groups at the 3-Position
}

\author{
Kozo Matsumoto $^{\dagger}$ Masaaki Shinohata, and Hitoshi YamaOKA $^{\dagger \dagger}$ \\ Department of Polymer Chemistry, Kyoto University, \\ Kyoto 606-8501, Japan
}

(Received June 30, 2000; Accepted August 23, 2000)

\begin{abstract}
Synthesis and anionic polymerization of 1,1-dimethyl-3-(1-naphthylmethyl) silacyclobutane (3-NMSB), 3-(4-biphenylmethyl)-1,1-dimethylsilacyclobutane (3-BMSB), and 1,1-dimethyl-3-(1-naphthyl)silacyclobutane (3-NSB) were investigated. 3-NMSB, 3-BMSB, and 3-NSB were synthesized by hydrosilation of 3-chloro-2-(1-naphthylmethyl)-1propene, 3-chloro-2-(4-biphenylmethyl)-1-propene, or 3-chloro-2-(1-naphthyl)-1-propene with chlorodimethylsilane followed by a treatment with magnesium, respectively. Butyllithium-induced polymerization of 3-NMSB, 3-BMSB, and 3NSB under a condition of $[\mathrm{M}]_{0} /[\mathrm{I}]_{0}=20 / 1\left([\mathrm{M}]_{0}\right.$ and $[\mathrm{I}]_{0}$ are the initial concentrations of monomer and initiator) in THF at $-78^{\circ} \mathrm{C}$ was carried out. Poly(3-NMSB) $\left(M_{\mathrm{n}}=3500, M_{\mathrm{w}} / M_{\mathrm{n}}=1.21\right)$, poly $(3-\mathrm{BMSB})\left(M_{\mathrm{n}}=4600, M_{\mathrm{w}} / M_{\mathrm{n}}=1.09\right.$, and poly $(3-$ NSB) $\left(M_{\mathrm{n}}=3200, M_{\mathrm{w}} / M_{\mathrm{n}}=1.16\right.$, where $M_{\mathrm{n}}$ and $M_{\mathrm{w}}$ were estimated by GPC using polystyrene as standards) were obtained. By differential scanning calorimetry (DSC) measurements, glass transition temperatures $\left(\mathrm{T}_{\mathrm{g}}\right)$ s were determined at $17^{\circ} \mathrm{C}$ for poly(3-NMSB), $28^{\circ} \mathrm{C}$ for poly(3-BMSB), and $39^{\circ} \mathrm{C}$ for poly $(3-\mathrm{NSB})$.
\end{abstract}

KEY WORDS Silacyclobutane / Naphthylsilacyclobutane / Biphenylsilacyclobutane / Anionic Polymerization / Ring-Opening Polymerization / Polysilacyclobutane /

Polycarbosilanes have recently received much attention as a new series of functional polymers. ${ }^{1}$ Ringopening polymerization of silacyclobutane is one of the most promising techniques to synthesize well-defined polycarbosilanes. ${ }^{2}$ The physical properties of those polymers are strongly affected by the substituents on the backbones, which consist of flexible silicon-carbon and carbon-carbon bonds. Among many polysilacyclobutane derivatives, polymers bearing a substituent at the 3 position are quite intriguing because they are considered as formal equivalents to alternating copolymers of silylenemethylene and vinyl monomer. We have already reported the facile methods to prepare 3-substituted polysilacyclobutane such as poly(3-methylenesilacyclobutane $)^{3}$ and poly(3-phenylsilacyclobutane). ${ }^{4}$ From the viewpoint of material science, aromatic substituents such as phenyl, naphthyl, and biphenyl groups are of particular interest. In this study, we prepared silacyclobutanes having 1-naphthylmethyl, 4-biphenylmethyl, and 1-naphthyl groups at the 3-position and examined their anionic polymerization. The obtained polymers are structurally equal to alternating copolymers of dimethylsilylenemethylene with 1-allylnaphthalene, 4-allylbiphenyl, and 1-vinylnaphthalene, respectively (Figure 1).

\section{EXPERIMENTAL}

\section{Materials}

3-Chloro-2-chloromethyl-1-propene was purchased from Aldrich, magnesium, 1,2-dibromoethane, hexachloroplatinic acid, 1-bromonaphthalene, 4-bromobiphenyl, triphenylphosphine, tetrachloromethane, lithium, and butyllithium hexane solution from Wako Pure Chemical Industry, chlorodimethylsilane from Shin-Etsu Chemical, $t$-butylhydroperoxide ( $70 \mathrm{wt} \%$ solution), selenium di- oxide, salicylic acid from Nacalai Tesque, and used as delivered. Tetrahydrofuran (THF) and diethyl ether were freshly distilled over sodium benzophenone ketyl under argon atmosphere before use. Lithium naphthalene was prepared by treatment of naphthalene with lithium metal in THF. l-Isopropenylnaphthalene was prepared as reported. ${ }^{5}$

\section{Measurements}

Gel-permeation chromatography was carried out in chloroform on a JASCO 880-PU chromatograph equipped with four polystyrene gel columns (Shodex K802 , K-803, K-804, and K-805; exclusion limit $=5 \times 10^{3}, 7$ $\times 10^{4}, 4 \times 10^{5}$, and $4 \times 10^{6}$, respectively) and JASCO 830 RI refractive index detector. Molecular weights of the<smiles>CC(C)(C)CC(Cc1cccc2ccccc12)CC(C)(C)C</smiles>

poly(3-NMSB)<smiles>CC(C)(C)CC(Cc1ccc(-c2ccccc2)cc1)CC(C)(C)C</smiles>

poly(3-BMSB)<smiles>CC(C)(C)CC(CC(C)(C)C)c1cccc2ccccc12</smiles>

poly(3-NSB)

Figure 1. Chemical structures of polysilacyclobutanes bearing aromatic groups at the 3-position.

\footnotetext{
${ }^{\dagger}$ To whom correspondence should be addressed.

${ }^{+\dagger}$ Present address: Department of Material Science, School of Engineering, University of Shiga Prefecture, 2500 Hassaka, Hikone 522-8533, Japan.
} 
polymers were calibrated with polystyrene standards. ${ }^{1} \mathrm{H}$ and ${ }^{13} \mathrm{C}$ NMR spectra were recorded on a JEOL GSX 270 spectrometer in $\mathrm{CDCl}_{3}$. Tetramethylsilane was used as the internal standard for NMR measurement. IR spectra were measured on a JASCO IR-810 spectrometer. Differential scanning calorimetry (DSC) measurements were performed on a MAC Science DSC 3100 at100 to $+150^{\circ} \mathrm{C}$ and found to be reproducible with no apparent hysteresis over three heating and two cooling scans at $10^{\circ} \mathrm{C} \mathrm{min}^{-1}$.

Preparation of 3-Chloro-2-(1-Naphthylmethyl)-1-Propene

A magnetic stirring bar and magnesium were charged in a three-necked $200 \mathrm{~mL}$ round- bottomed flask equipped with a reflux condenser, dropping funnel, rubber septum and rubber balloon. The flask was filled with argon. A THF (50 mL) solution of 1-bromonaphthalene $(6.95 \mathrm{~g}$, $50.0 \mathrm{mmol}$ ) was slowly added to the magnesium $(1.34 \mathrm{~g}$, $55.0 \mathrm{mmol})$. Then, an exothermic reaction occurred. After stirring for $2 \mathrm{~h}$, 1-naphthylmagnesium bromide solution thus prepared was added to a diethyl ether $(60 \mathrm{~mL})$ solution of 3 -chloro-2-(chloromethyl)-1-propene (6.94 $\mathrm{mL}, 60.0 \mathrm{mmol}$ ) at $0^{\circ} \mathrm{C}$ under an argon atmosphere. The mixture was stirred for $1 \mathrm{~h}$ at $0^{\circ} \mathrm{C}$ and $2 \mathrm{~h}$ at room temperature, and was poured into ice-cooled $1 \mathrm{M} \mathrm{HCl}$. The products were extracted with diethyl ether $(100 \mathrm{~mL} \times 3)$, dried over anhydrous $\mathrm{Na}_{2} \mathrm{SO}_{4}$, and concentrated. The residual oil was distilled under reduced pressure to give the title compound $(7.00 \mathrm{~g}, 32.5 \mathrm{mmol})$ in $65 \%$ yield. Bp $120-125^{\circ} \mathrm{C} / 0.5$ Torr. IR (neat) $3042,2946,2916,1597$, $1510,1442,1397,1259,909,790,775,659 \mathrm{~cm}^{-1} .{ }^{1} \mathrm{H}$ NMR $\left(\mathrm{CDCl}_{3}\right) \delta 3.96(\mathrm{~s}, 2 \mathrm{H}), 4.05(\mathrm{~s}, 2 \mathrm{H}), 4.82(\mathrm{~s}, 1 \mathrm{H})$, $5.22(\mathrm{~s}, 1 \mathrm{H}), 7.31-7.50(\mathrm{~m}, 4 \mathrm{H}), 7.73-8.05(\mathrm{~m}, 3 \mathrm{H}) .{ }^{13} \mathrm{C}$ NMR $\left(\mathrm{CDCl}_{3}\right) \delta 36.81,48.20,116.76,124.13,125.44$, 125.57, 125.90, 127.40, 127.61, 128.61, 132.14, 133.83, 134.17, 144.05. Anal. Calcd. for $\mathrm{C}_{14} \mathrm{H}_{13} \mathrm{Cl}$ : C, 77.59\%; $\mathrm{H}$, $6.05 \%$. Found: C, $77.75 \%$ H, $6.12 \%$.

Synthesis of 1,1-Dimethyl-3-(1-Naphthylmethyl)silacyclobutane (3-NMSB)

A magnetic stirring bar and hexachloroplatinic acid (10 mg) were charged in a two-necked $100 \mathrm{~mL}$ roundbottomed flask equipped with a reflux condenser, dropping funnel, and rubber balloon. The flask was filled with argon. While heating with a heat gun to $60^{\circ} \mathrm{C}$, a mixture of 3-chloro-2-(1-naphthylmethyl)-1-propene $(7.00 \mathrm{~g}, 32.5 \mathrm{mmol})$ and chlorodimethylsilane $(11.0 \mathrm{~mL}$, $99 \mathrm{mmol}$ ) was slowly added to the catalyst, then an exothermic reaction occurred. After the addition was completed, the mixture was stirred for $2 \mathrm{~h}$ at $60^{\circ} \mathrm{C}$. Then, the excess chlorodimethylsilane was removed under reduced pressure to give residual oil. The main product was 3chloro-2-(1-naphthylmethyl)propylchlorodimethylsilane, which was used for further transformation without purification. A magnetic stirring bar and magnesium (1.21 g, $60 \mathrm{mmol}$ ) were charged in another three-necked roundbottomed flask equipped with a reflux condenser under argon atmosphere. Tetrahydrofuran $(5 \mathrm{~mL})$ and 1,2dibromoethane $(0.3 \mathrm{~mL})$ were added and the mixture was heated with a heat gun to activate the magnesium. After an exothermic reaction, a solution of crude 3chloro-2-(1-naphthylmethyl) propylchlorodimethylsilane prepared above in THF $(60 \mathrm{~mL})$ was slowly added over a period of $10 \mathrm{~min}$. The mixture was then heated to reflux and stirred for $1 \mathrm{~h}$. The mixture was poured into icecooled $1 \mathrm{M} \mathrm{HCl}(200 \mathrm{~mL})$ and the products were extracted with hexane $(200 \mathrm{~mL})$. The organic layer was washed four times with water $(200 \mathrm{~mL})$ and dried over anhydrous $\mathrm{Na}_{2} \mathrm{SO}_{4}$ and concentrated. The residue was purified by silica-gel column chromatography to give the title compound $(4.80 \mathrm{~g}, 19.7 \mathrm{mmol}$, $)$ in $60 \%$ yield: IR (neat) 3040, 2852, 2900, 1510, 1395, 1247, 1129, 908, $846,775,718,650 \mathrm{~cm}^{-1} .{ }^{1} \mathrm{H}$ NMR $\left(\mathrm{CDCl}_{3}\right) \delta 0.19(\mathrm{~s}, 3 \mathrm{H})$, $0.28(\mathrm{~s}, 3 \mathrm{H}), 0.71-0.87(\mathrm{~m}, 2 \mathrm{H}), 1.05-1.18(\mathrm{~m}, 2 \mathrm{H}), 2.52$ $-2.73(\mathrm{~m}, 1 \mathrm{H}), 3.14(\mathrm{~d}, J=7.3 \mathrm{~Hz}, 1 \mathrm{H}), 7.25-7.54(\mathrm{~m}$, $4 \mathrm{H}), 7.63-8.10(\mathrm{~m}, 3 \mathrm{H}) .{ }^{13} \mathrm{C} \mathrm{NMR}\left(\mathrm{CDCl}_{3}\right) \delta-1.67,1.63$, $21.68,33.29,45.18,124.04,125.18,125.34,125.43$, 126.30, 126.45, 128.62, 131.98, 133.79, 137.44. Anal . Calcd. for $\mathrm{C}_{16} \mathrm{H}_{20} \mathrm{Si}$ : C, 79.93\%; $\mathrm{H}, 8.39 \%$. Found: C, $80.19 \% ; \mathrm{H}, 8.50 \%$. The monomer was dried by heating at $60^{\circ} \mathrm{C}$ for $2 \mathrm{~h}$ under vacuum pressure before polymerization.

Preparation of 3-Chloro-2-(4-Biphenylmethyl)-1-Propene

A tetrahydrofuran $(100 \mathrm{~mL})$ solution of 4-bromobiphenyl $(14.00 \mathrm{~g}, 60.0 \mathrm{mmol})$ was slowly added to the magnesium ( $1.70 \mathrm{~g}, 70.0 \mathrm{mmol})$. After stirring for $2 \mathrm{~h}, 1-$ naphthylmagnesium bromide solution thus prepared was added to a diethyl ether $(70 \mathrm{~mL})$ solution of 3-chloro2 -(chloromethyl)-1-propene $(8.00 \mathrm{~mL}, 71.0 \mathrm{mmol})$ at $0^{\circ} \mathrm{C}$ under an argon atmosphere. The mixture was stirred for $1 \mathrm{~h}$ at $0^{\circ} \mathrm{C}$ and $2 \mathrm{~h}$ at room temperature. Then resultant mixture was poured into ice-cooled $1 \mathrm{M} \mathrm{HCI}$, and the products were extracted with diethyl ether $(200 \mathrm{~mL} \times 3)$, dried over anhydrous $\mathrm{Na}_{2} \mathrm{SO}_{4}$, and concentrated. The residual oil was distilled under reduced pressure to give the title compound $(7.96 \mathrm{~g}, 32.8 \mathrm{mmol})$ in $55 \%$ yield. Bp $130-135^{\circ} \mathrm{C} / 0.5$ Torr. IR (neat) $3050,3026,1644,1488$, 1437, 1407, 1253, 925, 905, 758, 735, $688 \mathrm{~cm}^{-1}$. ${ }^{1} \mathrm{H} \mathrm{NMR}$ $\left(\mathrm{CDCl}_{3}\right) \delta 3.55(\mathrm{~s}, 2 \mathrm{H}), 3.99(\mathrm{~s}, 2 \mathrm{H}), 5.03(\mathrm{~s}, 1 \mathrm{H}), 5.22(\mathrm{~s}$, $1 \mathrm{H}), \quad 7.22-7.62 \quad(\mathrm{~m}, 9 \mathrm{H}) .{ }^{13} \mathrm{C} \mathrm{NMR} \quad\left(\mathrm{CDCl}_{3}\right) \delta \quad 39.33$, $47.41,116.23,126.94,127.12,127.19,128.70,129.42$, 137.38, 139.41, 140.82, 144.54. Anal. Calcd. for $\mathrm{C}_{16} \mathrm{H}_{15}$ Cl: C, 79.17\%; H, 6.23\%. Found: C, 79.28\%; H, 6.33\%.

\section{Synthesis of 1,1-Dimethyl-3-(4-Biphenyl)methylsilacy- clobutane (3-BMSB)}

A magnetic stirring bar and hexachloroplatinic acid $(10 \mathrm{mg}$ ) were charged in a two-necked $100 \mathrm{~mL}$ roundbottomed flask equipped with a reflux condenser, dropping funnel, and rubber balloon. The flask was filled with argon. While heating with a heat gun to $60^{\circ} \mathrm{C}$, a mixture of 3-chloro-2-(4-biphenylmethyl)-1-propene $(7.04 \mathrm{~g}, 29.0 \mathrm{mmol})$ and chlorodimethylsilane $(6.00 \mathrm{~mL}$, $54.0 \mathrm{mmol}$ ) were slowly added to the catalyst, then an exothermic reaction occurred. After the addition was completed, the mixture was stirred for $2 \mathrm{~h}$ at $60^{\circ} \mathrm{C}$. The excess chlorodimethylsilane was then removed under reduced pressure to give a residual oil. The main product was 3-chloro-2-(4-naphtylmethyl)propylchlorodimethylsilane, which was used for further transformation without purification. A magnetic stirring bar and magnesium ( $1.46 \mathrm{~g}, 60 \mathrm{mmol}$ ) were charged in another three-necked round-bottomed flask equipped with a reflux condenser under argon atmosphere. Tetrahydrofuran $(5 \mathrm{~mL})$ and 1,2 -dibromoethane $(0.3 \mathrm{~mL})$ were added to the magne- 
sium, and the mixture was heated with a heat gun to activate the magnesium. After an exothermic reaction, a solution of crude 3-chloro-2-(4-biphenylmethyl)propylchlorodimethylsilane prepared above in THF $(60 \mathrm{~mL})$ was slowly added over a period of $10 \mathrm{~min}$. The mixture was then heated to reflux and stirred for $1 \mathrm{~h}$. The mixture was poured into ice-cooled $1 \mathrm{M} \mathrm{HCl}(200 \mathrm{~mL})$ and the products were extracted with hexane $(200 \mathrm{~mL} \times 3)$, washed four times with water $(200 \mathrm{~mL})$ and dried over anhydrous $\mathrm{Na}_{2} \mathrm{SO}_{4}$ and concentrated. The residue was purified by silica-gel column chromatography to give the title compound ( $5.02 \mathrm{~g}, 18.9 \mathrm{mmol}$ ) in $65 \%$ yield: IR (neat) 3022, 2952, 2902, 1486, 1247, 1129, 906, 851, 808, $761,737,696 \mathrm{~cm}^{-1} .{ }^{1} \mathrm{H} \mathrm{NMR}\left(\mathrm{CDCl}_{3}\right) \delta 0.24(\mathrm{~s}, 3 \mathrm{H}), 0.28$ $(\mathrm{s}, 3 \mathrm{H}), 0.65-0.79(\mathrm{~m}, 2 \mathrm{H}), 1.08-1.21(\mathrm{~m}, 2 \mathrm{H}), 2.34-$ $2.56(\mathrm{~m}, 1 \mathrm{H}), 2.73(\mathrm{~d}, J=7.3 \mathrm{~Hz}, 2 \mathrm{H}), 7.20-7.65(\mathrm{~m}$, $9 \mathrm{H}) .{ }^{13} \mathrm{C} \mathrm{NMR}\left(\mathrm{CDCl}_{3}\right) \delta-1.62,1.58,21.30,34.21$, $47.71,126.73,126.82,126.88,128.61,129.17,138.37$, 140.66, 141.09. Anal. Calcd. for $\mathrm{C}_{18} \mathrm{H}_{22} \mathrm{Si}: \mathrm{C}, 81.14 \%$; $8.32 \%$. Found: C, $81.26 \%$;, $8.45 \%$.

\section{Preparation of 2-(1-Naphthyl)-2-Propen-1-Ol}

The method for oxidation of isopropenylbenzene reported by K. B. Sharpless et al. ${ }^{6}$ was applied to the synthesis. To a 500-mL round-bottomed flask, dichloromethane $(64 \mathrm{~mL})$, salicylic acid $(2.86 \mathrm{~g}, 20.7 \mathrm{mmol})$, selenium dioxide (1.16 mg, $10.5 \mathrm{~mL}$ ), and a magnetic stirring bar were charged. $87 \mathrm{~g}(\mathrm{ca} .67 \%, 744 \mathrm{mmol})$ of $t$ butylhydroperoxide was added, and the flask was immersed in a water bath. Then $30.2 \mathrm{~g}(180 \mathrm{mmol})$ of 1 isopropenylnaphthalene was slowly added. After stirring for 3 days, $200 \mathrm{~mL}$ of benzene was added and the volatile solvents were evaporated. The residue was dissolved in diethyl ether $(300 \mathrm{~mL})$ and poured into $1 \mathrm{M}$ aqueous $\mathrm{NaOH}$ solution and the organic layer was washed with water three times and concentrated. The products were dissolved in acetic acid $(80 \mathrm{~mL})$, then dimethyl sulfide $(40 \mathrm{~mL})$ was slowly added at $0^{\circ} \mathrm{C}$. The resulting solution was carefully neutralized with saturated aqueous $\mathrm{Na}_{2} \mathrm{CO}_{3}$ solution and the products were extracted with diethyl ether $(300 \mathrm{~mL} \times 3)$. The solution was dried over anhydrous $\mathrm{Na}_{2} \mathrm{SO}_{4}$ and concentrated. The residue was dissolved in methanol $(80 \mathrm{~mL})$ and $\mathrm{NaBH}_{4}(1.50 \mathrm{~g}, 40$ mmol) was added at $0^{\circ} \mathrm{C}$ and the mixture was stirred for $1 \mathrm{~h}$. The resulting mixture was poured into $1 \mathrm{M}$ aqueous $\mathrm{HCl}(200 \mathrm{~mL})$. The products were extracted with diethyl ether $(200 \mathrm{~mL} \times 3)$, dried over anhydrous $\mathrm{Na}_{2} \mathrm{SO}_{4}$ and concentrated. Distillation of the residue gave the title compound ( $17.2 \mathrm{~g}, 93.6 \mathrm{mmol})$ in $52 \%$ yield. Bp 115-125 ${ }^{\circ} \mathrm{C} / 0.7$ Torr. IR (neat) 3285 (broad OH), 3054, 2914, 2852, 1591, 1507, 1447, 1400, 1138, 1049, 912, 801, 775 $\mathrm{cm}^{-1} .{ }^{1} \mathrm{H} \mathrm{NMR}\left(\mathrm{CDCl}_{3}\right) \delta 1.50-1.85$ (broad s, $\left.1 \mathrm{H}\right), 4.46$ $(\mathrm{s}, 2 \mathrm{H}), 5.26(\mathrm{~s}, 1 \mathrm{H}), 5.70(\mathrm{~s}, 1 \mathrm{H}), 7.20-7.60(\mathrm{~m}, 4 \mathrm{H})$, $7.74-8.15(\mathrm{~m}, 3 \mathrm{H}) .{ }^{13} \mathrm{C} \mathrm{NMR}\left(\mathrm{CDCl}_{3}\right) \delta 66.69,114.79$, $125.14,125.32,125.61,125.78,126.04,127.78,128.27$, 131.42, 133.62, 137.84, 147.69. Anal. Calcd. for $\mathrm{C}_{13} \mathrm{H}_{12} \mathrm{O}$ : C, $84.75 \%$; H, 6.57\%. Found: C, $84.73 \%$; H, 6.62\%.

\section{Preparation of 3-Chloro-2-(1-Naphthyl)-1-Propene}

The chlorination method of allylic compounds reported by J. G. Calzada et $a l^{7}{ }^{7}$ was applied to the synthesis. To a solution of triphenylphosphine $(25.6 \mathrm{~g}, 98 \mathrm{mmol})$ in carbon tetrachloride $(66 \mathrm{~mL})$ was added $13.6 \mathrm{~g}$ ( $74 \mathrm{mmol})$ of 2-(1-naphthyl)-2-propen-1-ol, and the mixture was heated at $70^{\circ} \mathrm{C}$ for $1 \mathrm{~h}$ under argon atmosphere. After the solution had been cooled to room temperature, $100 \mathrm{~mL}$ of hexane was added and the precipitated triphenylphosphine oxide was removed by filtration. The filtrate was concentrated and distilled to give the title compound ( $13.6 \mathrm{~g}, 67.0 \mathrm{mmol})$ in $90 \%$ yield. Bp $70-75^{\circ} \mathrm{C} / 0.5$ Torr. IR (neat) 3042, 1591, 1508, 1439, 1262, 929, 802, 778, $753 \mathrm{~cm}^{-1} .{ }^{1} \mathrm{H} \mathrm{NMR}\left(\mathrm{CDCl}_{3}\right) \delta 4.43(\mathrm{~s}, 2 \mathrm{H}), 5.35(\mathrm{~s}, 1 \mathrm{H})$, $5.83(\mathrm{~s}, 1 \mathrm{H}) .7 .25-7.58(\mathrm{~m}, 4 \mathrm{H}), 7.72-8.03(\mathrm{~m}, 3 \mathrm{H}) .{ }^{13} \mathrm{C}$ NMR $\left(\mathrm{CDCl}_{3}\right) \delta 48.57,119.65,125.11,125.84,125.95$, 126.21, 128.13, 128.38, 131.25, 133.63, 137.38, 143.78 . Anal. Calcd. for $\mathrm{C}_{13} \mathrm{H}_{11} \mathrm{Cl}$ : C, 77.04\%; H, 5.47\%. Found: $\mathrm{C}, 77.22 \%$; $\mathrm{H}, 5.62 \%$.

\section{Synthesis of 1,1-Dimethyl-3-(1-Naphthyl) silacyclobutane (3-NSB)}

A magnetic stirring bar and hexachloroplatinic acid $(10 \mathrm{mg}$ ) were charged in a glass tube equipped with a Teflon screw-cock. A mixture of 3-chloro-2-(1-naphthyl)1-propene $(9.52 \mathrm{~g}, 47.0 \mathrm{mmol})$ and chlorodimethylsilane $(6.22 \mathrm{~mL}, 56.0 \mathrm{mmol})$ was added and the tube was sealed under vacuum pressure. The mixture was heated to $60^{\circ} \mathrm{C}$ for $5 \mathrm{~h}$. Then, the excess chlorodimethylsilane was removed under reduced pressure to give a mixture of 3 chloro-2-(1-naphthyl)propylchlorodimethylsilane, 1-isopropenylnaphthalene, and 2-(1-naphthyl)propylchlorodimethylsilane with catalyst residue. This mixture was used for further transformation without purification. A magnetic stirring bar and magnesium $(1.63 \mathrm{~g}, 67 \mathrm{mmol})$ were charged in a three-necked round-bottomed flask equipped with a reflux condenser under argon atmosphere. Tetrahydrofuran $(10 \mathrm{~mL})$ and 1,2-dibromoethane $(0.3 \mathrm{~mL})$ were added, and the mixture was heated with a heat gun to activate the magnesium. After an exothermic reaction, a solution of crude 3-chloro-2-(1-naphthyl)propylchlorodimethylsilane prepared above in THF (90 $\mathrm{mL}$ ) was slowly added over a period of $15 \mathrm{~min}$. The mixture was then heated to reflux and stirred for $1 \mathrm{~h}$. The mixture was poured into ice-cooled $1 \mathrm{M} \mathrm{HCl}(200 \mathrm{~mL})$ and the products were extracted with hexane $(200 \mathrm{~mL} \times$ 3 ), washed four times with water $(200 \mathrm{~mL})$, dried over anhydrous $\mathrm{Na}_{2} \mathrm{SO}_{4}$, and concentrated. The residue was purified by silica-gel column chromatography to give the title compound $(1.55 \mathrm{~g}, 5.80 \mathrm{mmol}$,) in $10 \%$ yield from 3 chloro-2-(1-naphthyl)-1-propene: IR (neat) 3045, 2960, 2908, 1593, 1508, 1396, 1248, 1115, 860,799, $770 \mathrm{~cm}^{-1}$. ${ }^{1} \mathrm{H} \mathrm{NMR}\left(\mathrm{CDCl}_{3}\right) \delta 0.18(\mathrm{~s}, 3 \mathrm{H}), 0.27(\mathrm{~s}, 3 \mathrm{H}), 1.31-1.50$ $(\mathrm{m}, 2 \mathrm{H}), 1.60-1.77(\mathrm{~m}, 2 \mathrm{H}), 4.20(\mathrm{tt}, J=8.1,11.0 \mathrm{~Hz}$, $1 \mathrm{H}), 7.42-7.65(\mathrm{~m}, 4 \mathrm{H}), 7.73(\mathrm{~d}, J=8.1 \mathrm{~Hz}, 1 \mathrm{H}), 7.89(\mathrm{~d}$, $J=7.3 \mathrm{~Hz}, 1 \mathrm{H}), 8.17(\mathrm{~d}, J=8.1 \mathrm{~Hz}, 1 \mathrm{H}) .{ }^{13} \mathrm{C} \mathrm{NMR}\left(\mathrm{CDCl}_{3}\right)$ $\delta-2.04,1.26,22.35,33.75,121.39,124.16,125.17$, 125.31, 125.47, 126.09, 128.62, 131.07, 133.86, 144.47. Anal. Calcd. for $\mathrm{C}_{15} \mathrm{H}_{18} \mathrm{Si}$ : C, $79.58 \%$; $\mathrm{H}, 8.01 \%$. Found: C, $79.28 \%$; $\mathrm{H}, 8.23 \%$.

\section{Polymerizations}

In a $50-\mathrm{mL}$ round-bottomed flask equipped with a magnetic stirring bar, rubber septum, and rubber balloon, was placed THF ( $6 \mathrm{~mL}$ ) under argon atmosphere. The solvent was titrated with a THF solution of lithium naphthalene to eliminate all reactive impurities. After the mixture was cooled to $-78^{\circ} \mathrm{C}$, butyllithium $(1.00 \mathrm{M}$ 
<smiles>C=C(CCl)Cc1cccc2ccccc12</smiles>

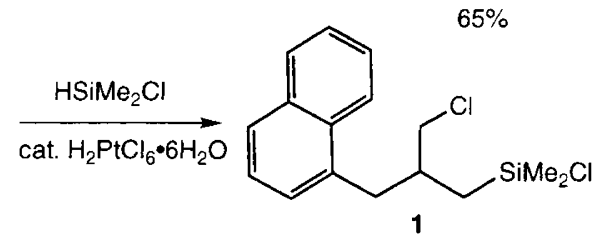

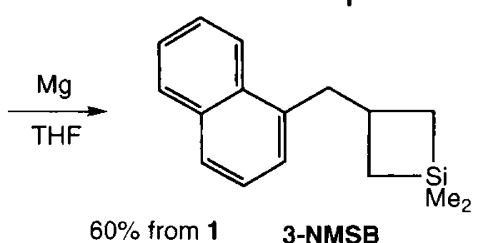

Scheme 1.<smiles>C=C(CCl)Cc1ccc(-c2cccc(C=C(CCl)CCl)c2)cc1</smiles>

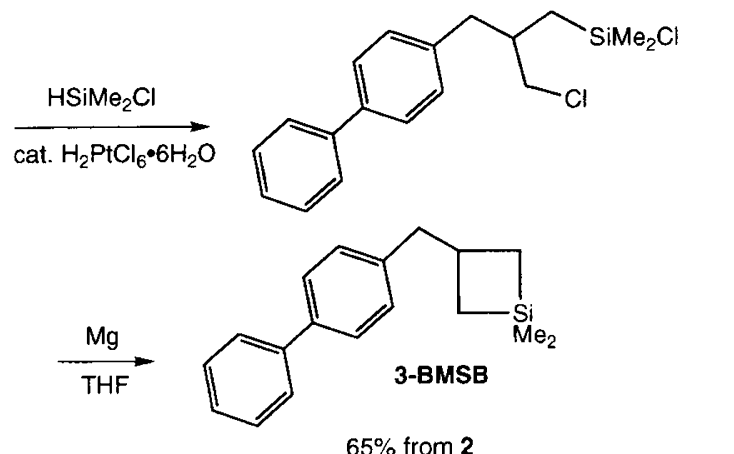

Scheme 2.

hexane solution, $0.15 \mathrm{mmol}$ ) was added, followed by silacyclobutane monomer $(3.0 \mathrm{mmol})$. The reaction mixture was stirred for the designated period. Water $(0.5 \mathrm{~mL})$ was added to terminate the polymerization. The resulting mixture was poured into water $(50 \mathrm{~mL})$ and extracted with toluene $(50 \mathrm{~mL})$. The organic layer was washed with water $(50 \mathrm{~mL})$ and dried over anhydrous $\mathrm{Na}_{2} \mathrm{SO}_{4}$. The volatile fractions were removed by evaporation. Monomer conversion was determined by ${ }^{1} \mathrm{H}$ NMR measurement of the crude products. The products were dissolved in a small amount of toluene and precipitated into excess methanol. The precipitate was dried in vacuo to give a poly(silacyclobutane).

\section{Poly (1,1-dimethyl-3-(1-naphthylmethyl) silacyclobutane) (poly(3-NMSB))}

IR (nujol) 1248, 838, 792, 770, $723 \mathrm{~cm}^{-1} .{ }^{1} \mathrm{H}$ NMR $\left(\mathrm{CDCl}_{3}\right) \delta-0.29-0.02(\mathrm{~m}, 6 \mathrm{nH}), 0.25-0.63(\mathrm{~m}, 4 \mathrm{nH})$, $0.70-0.88(\mathrm{~m}, 6 \mathrm{H}), 1.02-1.30(\mathrm{~m}, 4 \mathrm{H}), 1.88-2.20(\mathrm{~m}$, $\mathrm{nH}), 2.58-2.98(\mathrm{~m}, 2 \mathrm{nH}), 6.96-8.02(\mathrm{~m}, 7 \mathrm{nH}) .{ }^{13} \mathrm{C} \mathrm{NMR}$<smiles>C=C(CO)c1cccc2ccccc12</smiles>

$52 \%$<smiles>C=C(CCl)c1cccc2ccccc12</smiles>

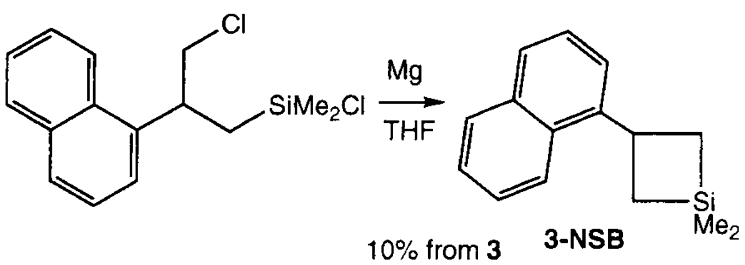

Scheme 3.

$\left(\mathrm{CDCl}_{3}\right) \delta \quad-1.33,-0.94,-0.66, \quad 25.48, \quad 32.05, \quad 43.38$, 123.92 , 125.09, 125.29, 126.35, 127.11, 128.59, 132.23, 133.71, 137.58. Anal. Calcd. for $\mathrm{C}_{292} \mathrm{H}_{370} \mathrm{Si}_{18}$ : C, 79.97\%; $\mathrm{H}, 8.50 \%$. Found: C, $79.71 \% ; \mathrm{H}, 8.63 \%$.

\section{Poly(1,1-dimethyl-3-(4-biphenylmethyl) silacyclobutane) (poly(3-BMSB))}

IR (nujol) $1248,845,760,750,723,697 \mathrm{~cm}^{-1} .{ }^{1} \mathrm{H}$ NMR $\left(\mathrm{CDCl}_{3}\right) \delta-0.12-0.15(\mathrm{~m}, 6 \mathrm{nH}), 0.38-0.78(\mathrm{~m}, 4 \mathrm{nH})$, $0.82-0.93(\mathrm{~m}, 6 \mathrm{H}), 1.12-1.36(\mathrm{~m}, 4 \mathrm{H}), 1.78-2.02(\mathrm{~m}$, $\mathrm{nH}), 2.32-2.66(\mathrm{~m}, 2 \mathrm{nH}), 6.98-7.67(\mathrm{~m}, 9 \mathrm{nH}) .{ }^{13} \mathrm{C} \mathrm{NMR}$ $\left(\mathrm{CDCl}_{3}\right) \delta \quad-1.23,-0.83,-0.51,24.72,24.81,32.95$, $46.23,126.68,126.79,128.62,129.54,138.26,140.71$, 140.85. Anal. Calcd. for $\mathrm{C}_{346} \mathrm{H}_{428} \mathrm{Si}_{19}$ : C, 81.15\%; $\mathrm{H}$, $8.42 \%$. Found: C, $80.72 \%$;, $8.56 \%$.

Poly (1,1-dimethyl-3-(1-naphthyl) silacyclobutane) (poly(3-NSB))

IR (nujol) $1248,1168,870,838,770,723 .{ }^{1} \mathrm{H}$ NMR $\left(\mathrm{CDCl}_{3}\right) \delta-0.90--0.25(\mathrm{~m}, 6 \mathrm{nH}), 0.40-1.34(\mathrm{~m},(4 \mathrm{n}+$ $10) \mathrm{H}), 2.80-3.10+3.25-3.58(\mathrm{~m}, \mathrm{nH}), 6.82-8.03(\mathrm{~m}$, $7 \mathrm{nH}) .{ }^{13} \mathrm{C} \mathrm{NMR}\left(\mathrm{CDCl}_{3}\right) \delta-2.25,-1.88,28.98,29.87$, $30.02,30.20,122.80,123.41,124.94,125.35,125.73$, 126.68, 128.82, 130.65, 133.66, 145.57. Anal. Calcd. for $\mathrm{C}_{289} \mathrm{H}_{352} \mathrm{Si}_{19}$ : C, 79.62\%; H, 7.14\%. Found: C, 79.16\%; H, $8.20 \%$.

\section{RESULTS AND DISCUSSION}

Synthesis of 3-NMSB, 3-BMSB, and 3-NSB

Schemes 1 and 2 show the synthetic routes of 3-NMSB and 3-BMSB. These monomers were synthesized via three steps with relatively good yields. The addition of Grignard reagents to 3-chloro-2-chloromethyl-1-propene was the key step. By adding Grignard reagents to a diethyl ether solution of 3-chloro-2-chloromethyl-1-propene, 1:1 adducts were predominantly obtained with small amount of $2: 1$ adducts, which were easily separated by distillation. These compounds were effectively transformed into chlorosilanes by hydrosilation with chlorodi- 


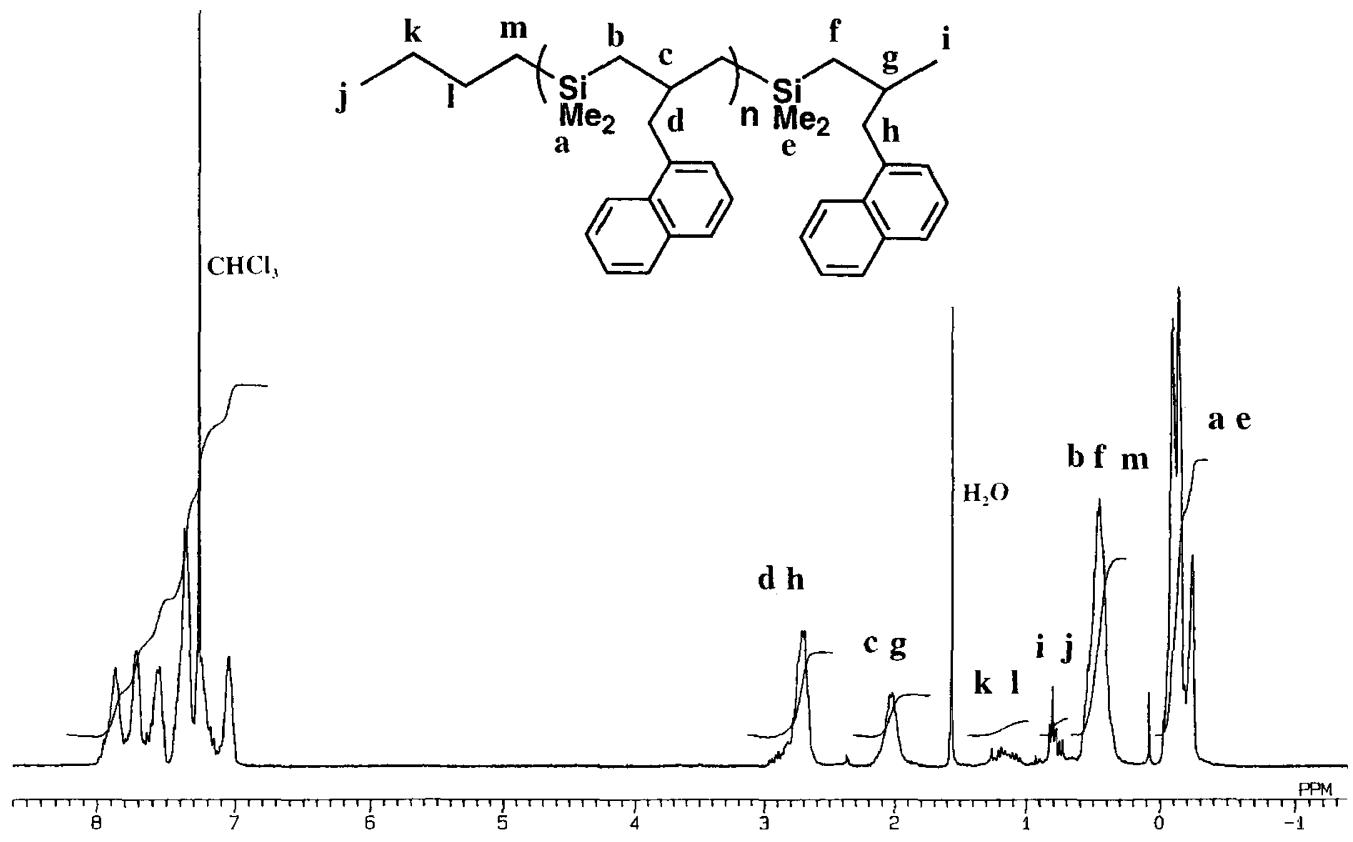

Figure 2. ${ }^{1} \mathrm{H}$ NMR spectrum of poly(3-NMSB) in $\mathrm{CDCl}_{3}$.
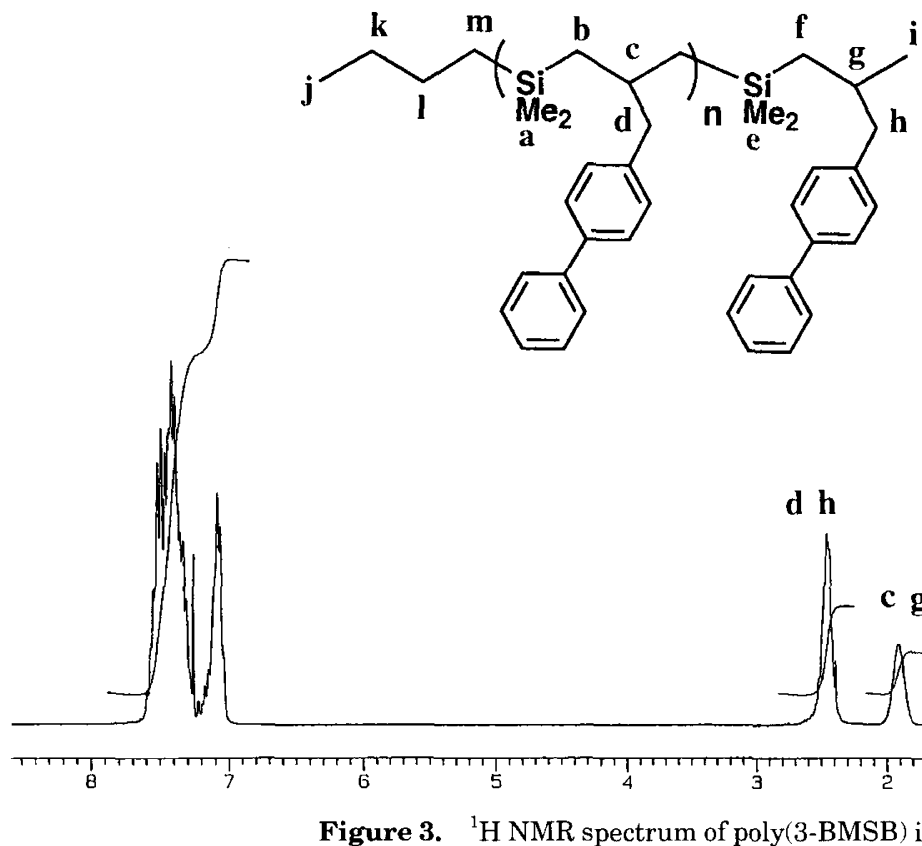

methylsilane and the crude compounds were exposed to magnesium without purification to give 3-NMSB and 3$\mathrm{BMSB}$, respectively. The overall yields of 3-NMSB and 3 -BMSB were $39 \%$ and $36 \%$, respectively.

Compared with the synthesis of the above monomers, that of 3-NSB was somewhat difficult (Scheme 3). 2-(1Naphthyl)-3-chloro-1-propene was prepared by oxidation and chlorination of 1-isopropenylnaphthalene. Hydrosilation of the compound with chlorodimethylsilane gave the desired chlorosilane but in very low yield. The main product of the hydrosilation was reduction product, 1isopropenylnaphthalene. The hydrosilated product was treated with magnesium to provide $3-\mathrm{NSB}$. The overall yield of 3-NSB from 1-isopropenylnaphthalene was $4.6 \%$.

\section{Polymerization of 3-NMSB, 3-BMSB, and 3-NSB}

3 -NMSB, 3-BMSB, and 3-NSB were polymerized in THF at $-78^{\circ} \mathrm{C}$ using butyllithium as an initiator. The results are summarized in Table I. During the polymerization, the color of each solution turned yellow to dark red, indicating that the electron transfer from the propagating anion to aromatic group of the polymer might occur. It took more than $4 \mathrm{~h}$ to attain approximately $90 \%$ monomer-conversion under a condition of $[\mathrm{M}]_{0} /[\mathrm{I}]_{0}=20 / 1$ and $[\mathrm{M}]_{0}=1.0 \mathrm{M}$. Compared to the polymerization of 1,1 - 


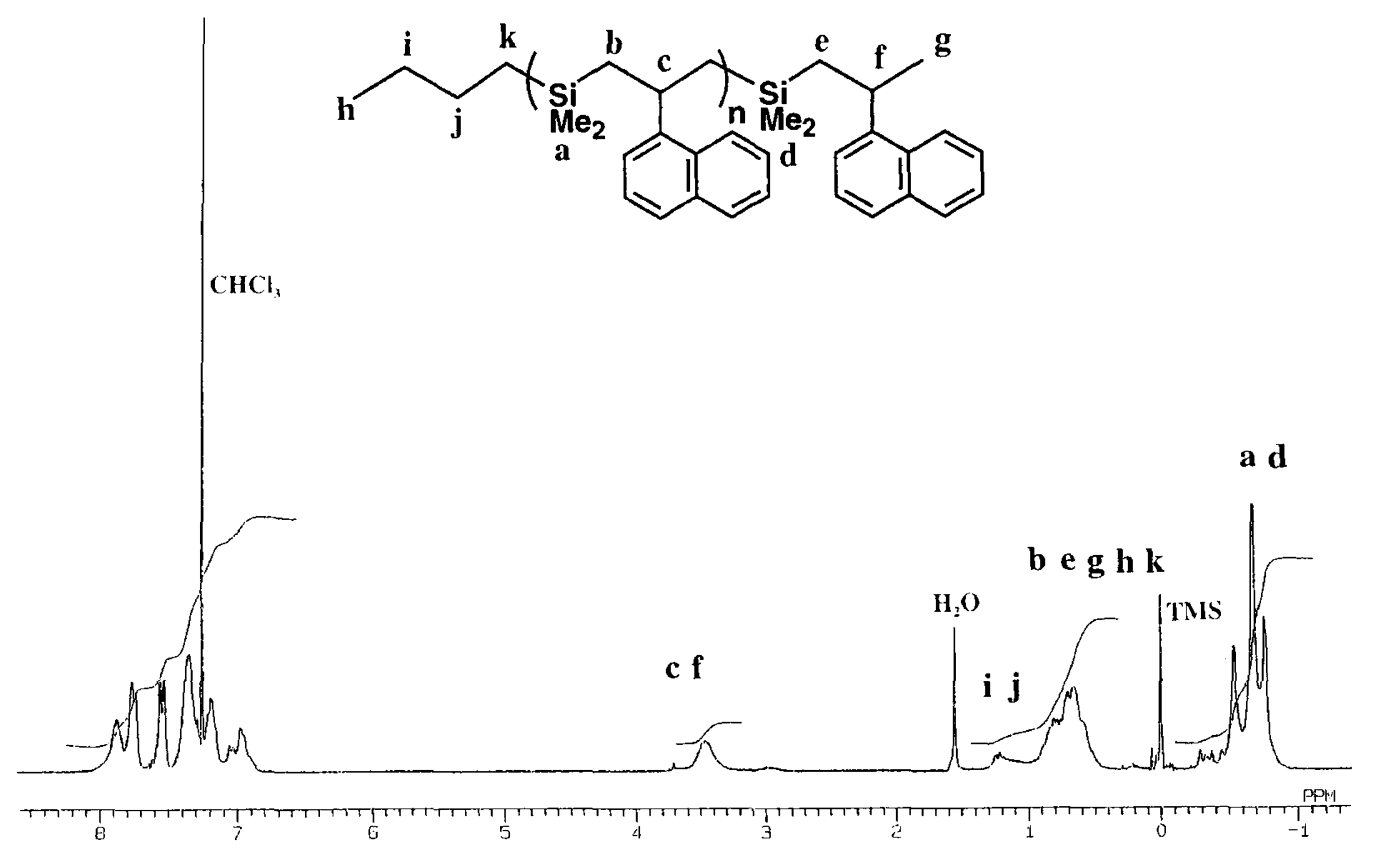

Figure 4. ${ }^{1} \mathrm{H}$ NMR spectrum of poly(3-NSB) in $\mathrm{CDCl}_{3}$.
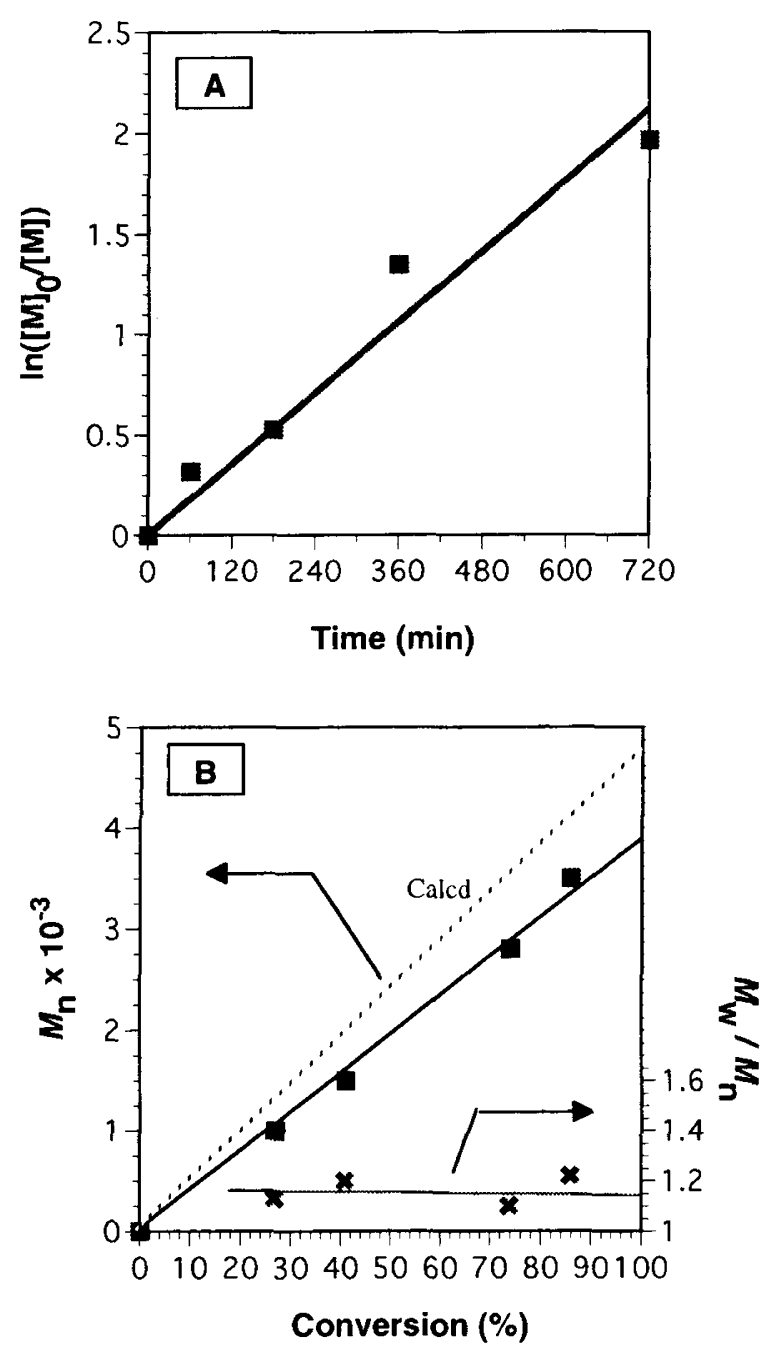

Figure 5. $\ln \left([\mathrm{M}]_{0} /[\mathrm{M}]\right)$-time relationship (A) and $M_{\mathrm{n}}$-monomer conversion and $M_{\mathrm{w}} / M_{\mathrm{n}}$-monomer conversion relationships $(\mathbf{B})$ in the polymerization of 3-NMSB under the condition of $[\mathrm{M}]_{0}=1.0 \mathrm{M}$, $[\mathrm{M}]_{0} /[\mathrm{I}]_{0}=20 / 1$, in THF at $-78^{\circ} \mathrm{C}$.
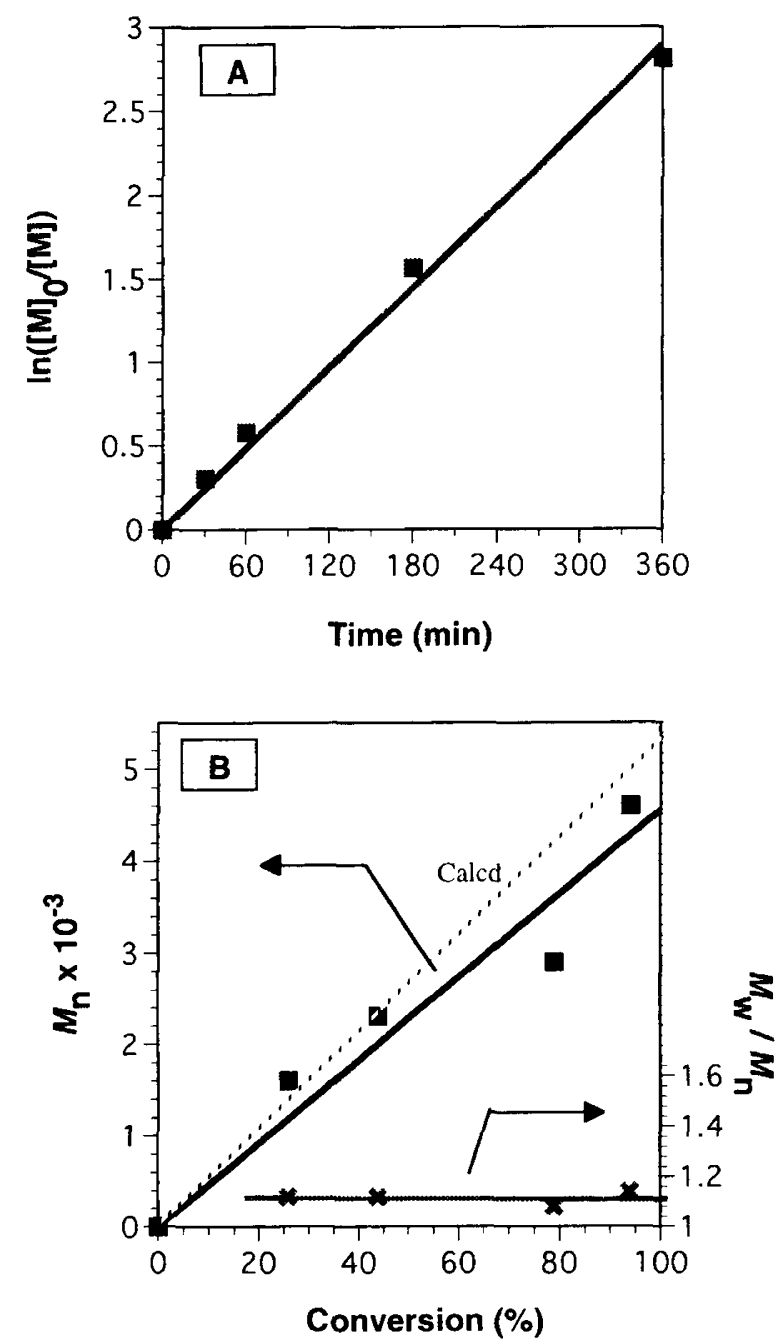

Figure 6. $\ln \left([\mathrm{M}]_{0} /[\mathrm{M}]\right)$-time relationship (A) and $M_{\mathrm{n}}-$ monomer conversion and $M_{\mathrm{w}} / M_{\mathrm{n}}$-monomer conversion relationships $(\mathbf{B})$ in the polymerization of 3-BMSB under the condition of $[\mathrm{M}]_{0}=1.0 \mathrm{M}$, $[\mathrm{M}]_{0} /[\mathrm{I}]_{0}=20 / 1$, in THF at $-78^{\circ} \mathrm{C}$. 
Table I. Results of butyllithum-induced polymerization of 3-NMSB, 3-BMSB, and 3-NSB ${ }^{\text {a }}$

\begin{tabular}{|c|c|c|c|c|c|c|}
\hline Monomer & $\frac{\text { Time }}{h}$ & $\frac{\text { Conversion }}{\%}$ & $\frac{M_{\mathrm{n}}}{\text { Calcd. }^{\mathrm{b}}}$ & $\frac{M_{\mathrm{n}}}{\mathrm{GPC}^{\mathrm{c}}}$ & $\frac{M_{\mathrm{n}}}{{ }^{1} \mathrm{H} \mathrm{NMR}^{\mathrm{d}}}$ & $\frac{M_{\mathrm{w}} / M_{\mathrm{n}}}{\mathrm{GPC}^{\mathrm{c}}}$ \\
\hline & 12 & 86 & 4900 & 350 & 4000 & 1.2 \\
\hline & 6 & & & 66 & 5900 & 1.14 \\
\hline 3 -NSB & 4 & 92 & 4200 & 3200 & - & 1.16 \\
\hline
\end{tabular}

${ }^{\mathrm{a}}$ Polymerization was carried out in THF at $-78^{\circ} \mathrm{C},[\mathrm{M}]_{0}=1.0 \mathrm{M}$, $[\mathrm{M}]_{0} /[\mathrm{I}]_{0}=20 / 1 .{ }^{\mathrm{b}}$ Calculated from the amount of consumed monomer to the initiator. ${ }^{c}$ Determined by GPC using polystyrene standards. ${ }^{\mathrm{d}}$ Determined by ${ }^{1} \mathrm{H}$ NMR measurements.

dimethyl-3-phenylsilacyclobutane in THF at $-78^{\circ} \mathrm{C}$ under a condition of $[\mathrm{M}]_{0} /[\mathrm{I}]_{0}=20 / 1,[\mathrm{M}]_{0}=500 \mathrm{mM}$, which was completed within $1 \mathrm{~h},{ }^{4}$ polymerization rates of these monomers were considerably slow. This might be caused by the electron transfer or by large steric hindrance around the active species. Nevertheless, the numberaverage molecular weight $\left(M_{n}\right)$ of the obtained polymer estimated by GPC relative to polystyrene standards was almost the same as that calculated from the amount of consumed monomer to an initiator.

Figures 2-4 show the ${ }^{1} \mathrm{H}$ NMR spectra of the obtained polymers. Assignments of the signals are given in the figures. In all cases, three methyl signals due to the methyl groups on the silicon atoms were observed, indicating the formation of atactic polymers. In the spectra of poly(3-NMSB) and poly(3-BMSB), both initiation end and termination end methyl groups ( $\boldsymbol{i}$ and $\boldsymbol{j}$ ) were seen clearly around $0.8 \mathrm{ppm}$. The $M_{\mathrm{n}}$ s estimated from the integral ratios of the internal methylene groups around $0.5 \mathrm{ppm}$ to the end groups at $0.8 \mathrm{ppm}$ were 4000 for poly(3-NMSB) and 5900 for poly(BMSB) respectively, which were in good agreement with $M_{\mathrm{n}} \mathrm{s}$ calculated from the ratios of the consumed amount of monomers to the initiator. The end group signals were not observed so clearly in the case of poly(3-NSB) that $M_{n}$ could not be estimated by ${ }^{1} \mathrm{H}$ NMR measurement for the polymer.

Figures $5 \mathrm{~A}$ and $6 \mathrm{~A}$ show the $\ln \left([\mathrm{M}]_{0} /[\mathrm{M}]\right)$-time relation in the polymerization of 3-NMSB and 3-BMSB. Linear relations of $\ln \left([\mathrm{M}]_{0} /[\mathrm{M}]\right)$-time indicate no serious termination in the polymerization. Figures $5 \mathrm{~B}$ and $6 \mathrm{~B}$ show the $M_{\mathrm{n}}$-monomer conversion relations in the polymerization of 3-NMSB and 3-BMSB along with $M_{\mathrm{w}} / M_{\mathrm{n}}-$ monomer conversion relations. Linear relations of $M_{\mathrm{n}}-$ monomer conversion were observed in both polymerizations, indicating no rapid chain-transfer in the polymerizations. We have not confirmed those relationships for 3NSB yet because a sufficient amount of the monomer could not be obtained for this experiment. The results in Figures 5 and 6 may suggest a living nature of the polymerization of 3-NMSB and 3-BMSB, however, we should not conclude that these polymerizations were living because of the following two reasons. 1. The $M_{\mathrm{n}} s$ of the polymers shown in the figures were estimated relative to polystyrene standards and did not represent the actual molecular weight. 2 . The $[\mathrm{M}]_{0} /[\mathrm{I}]_{0}$ in these experiments was merely twenty and not large enough to detect the effect of side reactions. More precise experiments under larger $[\mathrm{M}]_{0} /[\mathrm{I}]_{0}$ condition or sequential monomer addition experiments were needed to discuss the living nature.

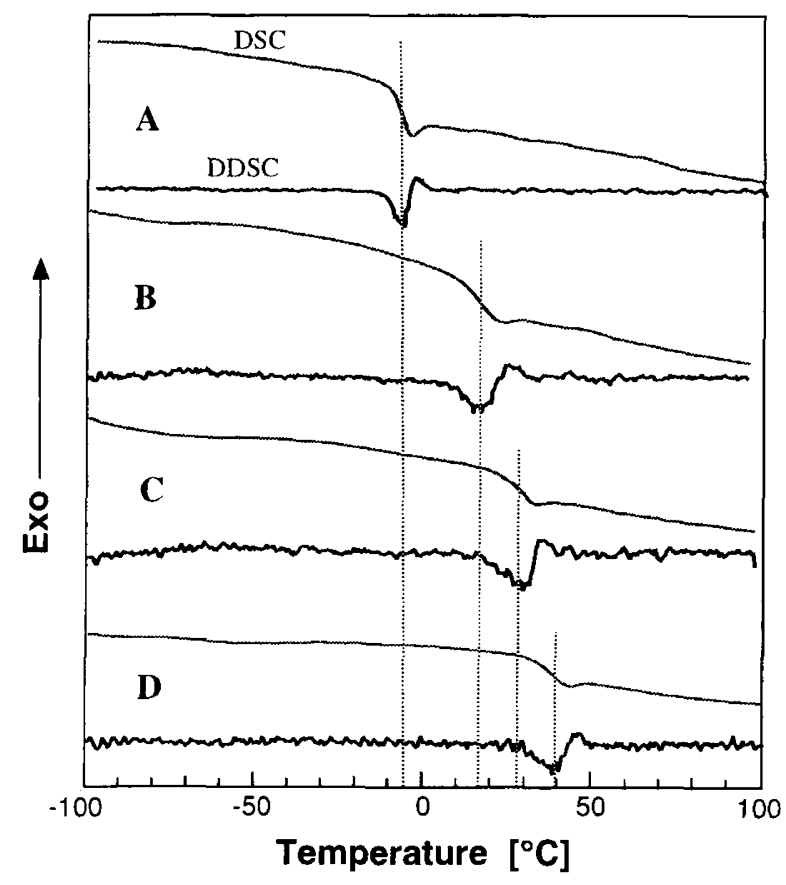

Figure 7. GPC traces for the second heating scan at $10^{\circ} \mathrm{C} \mathrm{min}-1$ (upper curves) and DDSC curves for the second heating scan (lower curves). A: poly(3-PSB), B: poly(3-NMSB), C: poly(3-BNSB), D: $\operatorname{poly}(3-\mathrm{NSB})$.

Differential Scanning Calorimetry (DSC) Measurement of Aromatic Group Substituted Polysilacyclobutanes

DSC of the naphthyl or biphenyl-substituted polymers synthesized above was taken. Glass transition of the polymers was observed around room temperature. Glass transition temperatures $\left(T_{\mathrm{g}}\right) \mathrm{s}$ were determined at $17^{\circ} \mathrm{C}$ for poly(3-NMSB), $28^{\circ} \mathrm{C}$ for poly(3-BMSB), and $39^{\circ} \mathrm{C}$ for poly $(3-\mathrm{NSB})$, from the inflection point on the second DSC heating curve by the differential calculus of DSC curves (DDSC). The charts are given in Figure 7. For comparison, the DSC chart of poly(1,1-dimethyl-3-phenylsilacyclobutane) (poly(3-PSB), $M_{n}=4100, M_{\mathrm{w}} / M_{\mathrm{n}}=$ 1.11) reported previously ${ }^{4}$ is also shown in the figure. Poly(3-NMSB), poly(3-BMSB), and poly(3-NSB) had much higher $T_{\mathrm{g}}$ than the poly(1,1-dimethyl-3-phenylsilacyclobutane). The backbone stiffness was clearly increased by introducing larger aromatic substitutents. The flexible silatrimethylene moieties can easily reflect the properties of the substituents.

\section{CONCLUSIONS}

We synthesized three aromatic-group-substituted silacyclobutanes, 1,1-dimethyl-3-(1-naphthylmethyl)silacyclobutane, 3-(4-biphenylmethyl)-1,1-dimethylsilacyclobutane, and 1,1-dimethyl-3-(1-naphthyl)silacyclcobutane, and examined their anionic polymerization. The polymerization of these monomers proceeded in a controlled manner to give the corresponding polysilacyclobutanes, which are considered structurally as alternating copolymer of dimethylsilylenemethylene and ally or vinyl aromatics. DSC analysis revealed that polysilacylcobutanes synthesized here had relatively high $T_{\mathrm{g}} \mathrm{s}$ compared to poly(3-phenylsilacyclobutane). These results demon- 
strated that the stiffness of the polymer backbone could easily be modified by the introduction of various aromatic substituents. This may be one of the most remarkable advantages of the flexible polycarbosilanes.

Acknowledgments. The present work was supported by a Grant-in-aid for Encouragement of Young Scientists (No. 11750764) and by CASIO SCIENCE PROMOTION FOUNDATION.

\section{REFERENCES}

1. a) M. Zeldin, K. J. Wynne, and H. R. Allcock, "Inorganic and Organometallic Polymers", ACS Symposium Series 360, American Chemical Society, Washington, DC, 1988 . b) J. M. Zeigher and F. W. G. Fearon, "Silicon-Based Polymer Science", Advances in Chemistry Series 224, American Chemical Society, Washington, DC, 1990 . c) J. G. Richard, "SiliconContaining Polymers", The Royal Society of Chemistry, Cambridge, 1995. d) H. R. Kricheldorf, "Silicon in Polymer Synthesis", Springer-verlag, Berlin, 1996.

2. a) C. X. Liao and W. P. Weber, Macromolecules, 25, 1639
(1992). b) M. Theurig, S. J. Sargeant, G. Manuel, and W. P. Weber, Macromolecules, 25, 3834 (1992). c) M. Theurig and W. P. Weber, Polym. Bull., 28, $17(1992)$. d) C. X. Liao and W. P. Weber, Polym. Bull., 28, 281 (1992). e) H. Yamashita, M. Tanaka, and K. Honda, J. Am. Chem. Soc., 117, 8873 (1995). f) K. Matsumoto and H. Yamaoka, Macromolecules, 28, 7029 (1995). g) K. Matsumoto, H. Shimazu, M. Deguchi, and H. Yamaoka, J. Polym. Sci., Part A: Polym. Chem., 35, 3207 (1997). h) K. Matsumoto, M. Deguchi, M. Nakano, and H. Yamaoka, J. Polym. Sci., Part A. Polym. Chem., 36, 2699 (1998). i) R. Knischka, H. Frey, U. Rapp, and F. J. Mayer-Posner, Macromol. Rapid. Commun., 19, 455 (1998). j) K. Komuro and Y. Kawakami, Polym. J., 31, 138 (1999).

3. K. Matsumoto, K. Miyagawa, and H. Yamaoka, Macromolecules, 30, 2524 (1997)

4. K. Matsumoto, M. Shinohata, and H. Yamaoka, Polym. J. 32, $354(2000)$

5. I. I. Lapkin and M. N. Rybakova, Zhur. Obshchei Khim., 30, $2674(1960)$.

6. M. A. Umbreit and K. B. Sharpless, J. Am. Chem. Soc., 99, 5526 (1977).

7. J. G. Calzada and J. Hooz, Org. Synth., VI, 634 (1988). 